Rothery rule. The importance of structure determ. ination was stressed by Prof. G. V. Raynor, of the University of Birmingham, who made a plea for more structure results to help the theoretician.

That complete structure determination is not always necessary was shown by Dr. Hume-Rothery, who discussed the $\gamma$-copper-gallium phases; as excess of gallium is added, related structures are formed, and, although the atomic positions have not been determined, it is evident from density measurements that the number of atoms in equivalent unit cells decreases. This behaviour, which is exactly similar to that of copper-aluminium alloys, appears to be caused by attempts to maintain a constant value for the number of electrons per unit cell ${ }^{10}$; this concept may well prove more fruitful than the number of electrons per atom in accounting for structures with vacant sites, such as $\mathrm{Mn}_{8} \mathrm{SiAl}_{9}$.

Mr. H. J. Goldschmidt, of the B.S.A. Group Research Centre, Sheffield, gave a practical bias to this session of the conference. He showed how structural considerations provide a basis for the classification of carbides, and described, with a wealth of detail, how it is possible to predict which carbides will be present in a steel of given composition.

\section{Structural Perturbations}

Not all structures are perfect, and the diffraction effects given by certain imperfect structures provide fascinating material for study. Perhaps the best known of these defects is that which occurs in cobalt ${ }^{11}$, and an attempt at a theoretical explanation of the structure was given by Dr. J. W. Christian, of Oxford. He described the transformation from cubic to hexagonal cobalt as martensitic in nature-that is, occurring by glides of planes of atoms over each other. No purely mechanistic description, however, can be said to 'explain' the faults ; energy considera. ations must be the final arbiter, and Dr. Christian made no attempts to deal with these.

Dr. K. H. Jack, of the University of Durham, described how, in carbon and nitrogen martensites, precipitation of a new phase, such as cementite, may start as platelets only a few unit cells thick, so that one of the Laue conditions for X-ray reflexion is relaxed. He described the effect of this phenomenon on X-ray powder photographs. Platelets of this type seem to provide a favoured mode of precipitation, as shown by the classical work of Preston ${ }^{12}$ and Guinier ${ }^{13}$ on age-hardening aluminium alloys. Dr. A. Taylor, of the Mond Nickel Co., Birmingham, also discussed the martensite structure, and compared the development of this tetragonal structure to that occurring in the copper-manganese system; here the axial ratio changes abruptly from unity and thus he saw no reason why cubic martensite should not occur at low carbon concentrations.

Dr. J. B. Newkirk, of the Cavendish Laboratory, described the diffraction effects given by single crystals of the alloy CoPt; streaks pass through the $\mathrm{X}$-ray reflexions, and these again probably represent the incipient formation of platelets. An experimental approach to the study of such phenomena was described by Dr. H. Lipson, of the Manchester College of Technology; he described how diffraction gratings of $1 \mathrm{~mm}$. spacing were made with different degrees of short-range order, and how the diffraction patterns in visible light ${ }^{14}$ could be compared with X-ray diffraction patterns. Although only twodimensional, the method had been used with some success to account for the diffraction effects from
$\mathrm{AuCu}_{3}{ }^{15}$, and Dr. Lipson showed a ciné film which demonstrated the growth of superlattice lines from the background of a diffraction photograph.

That such studies are not only of academic interest was shown by Mr. T. R. Pomeroy, of the British Non-Ferrous Metals Research Association. $\mathrm{He}$ described how the corrosion properties of ironnickel-copper alloys were found to depend upon the development of a periodic structure before dissociation $^{16}$, and explained how this structure had been detected by means of the electron microscope.

From all these results, and many others which were mentioned in discussion, it was evident that the subject is developing along very healthy lines; theoretical and practical academic work are proceeding in parallel with technical applications, each being dependent upon and invigorating the others. Considerable progress may be expected in the next ten years in our understanding of the metallic state, which at present provides so many persistent but fascinating problems.

${ }^{1}$ Stokes, A. R., Proc. Phys. Soc., 61, 382 (1948).

${ }^{2}$ Averbach, B. L., and Warren, B. E., J. App. Phys, 20, 885 (1949).

${ }^{2}$ Berg, W. F., Z. Krist., 89, 286 (1934).

"Barrett, C. S., Amer. Inst, Min. Met. Eng., Tech. Pub., 1865 (1945).

${ }^{5}$ Sucksmith, W., Proc. Roy. Soc., A, 170, 551 (1939).

' Sykes, C., and Jones, F. W., J. Inst. Metals, 59, 257 (1936).

? Tucker, C. W., A.E.C.D. Report No. 2957 (1950).

${ }^{8}$ Ito, T., Nature, 164, 755 (1949).

Bradiey, A. J., and Cheng, C. S., Z. Krist., 99, 480 (1938).

${ }^{20}$ Bradley, A. J., Goldschmidt, H. J., and Lipson, H., J. Inst. Metals, 63, 149 (1938). "I Edwards, O. S. Silipson, H., and Wilson, A. J. C., Proc, Roy. Soc.,

${ }^{12}$ Preston, G. D., Proc. Roy. Soc., A, 167, 528 (1938).

${ }^{13}$ Guinier, A., Proc. Phys. Soc., 57, 310 (1945).

${ }^{14}$ Bragg, W. I., and Lipson, H., J. Sci. Instr., 20, 110 (1943).

${ }^{16}$ Edmunds, I. G., Hinde, R. M., and Lipson, H., Nature, 160, 304 (1947).

${ }^{16}$ Daniel, V., and Lipson, H., Proc. Roy. Soc., A, 181, 368 (2943). 182, $378^{\prime}(1944)$.

\section{UNITED STATES NATIONAL ACADEMY OF SCIENCES}

$A \mathrm{~T}$ the annual general meeting of the United A States National Academy of Sciences, held in Washington, D.C., during April 23-25, the following officers, new members and foreign associates were elected.

Home Secretary : A. Wetmore, at present secretary of the Smithsonian Institution, for a four-year term, in succession to Dr. F. E. Wright, formerly of the Carnegie Institution of Washington, who has been home secretary of the Academy for the past twenty years.

New Members of Council: J. W. Beams, chairman of the School of Physics, University of Virginia ; and E. C. Stakman, chief of the Division of Plant Pathology and Botany, University of Minnesota.

New Members: W. C. Allee, head of the Department of Biology, University of Florida; N. E. Bradbury, director of Los Alamos Scientific Laboratory, Los Alamos, N.M.; D. Brouwer, director of Yale Observatory, New Haven; R. E. Clausen, chairman of the Division of Genetics, University of California; E. DeGolyer, senior partner of DeGolyer and MacNaughton, Dallas; J. T. Edsall, associate professor of biological chemistry, Harvard Medical School; R. M. Fuoss, Sterling professor of chemistry, Yalo University; R. Gunn, director of the Division of Physical Research, U.S. Weather Bureau, Washing- 
ton, D.C. ; H. F. Harlow, chairman of the Depart ment of Psychology, University of Wisconsin; C. O'D. Iselin, senior physical oceanographer, Woods Hole Oceanographic Institution, Woods Hole, Mass. ; R. Kellogg, director of the U.S. National Museum Washington, D.C. ; R. H. Kent, associate director of the Ballistic Research Laboratories, Aberdeen Proving Ground, Maryland ; D. W. Kerst, professor of physics, University of Illinois; C. C. G. King, director of the Nutrition Foundation, New York ; S. K. Lothrop, curator of Andean archæology, Peabody Museum, Harvard University ; T. B. Nolan, assistant director of the U.S. Geological Survey, Washington, D.C. E. M. Purcell, professor of physics, Harvard University ; A. J. Riker, professor of plant pathology, University of Wisconsin; H. P. Robertson, professor of mathematical physics, California Institute of Technology (on leave to the Weapons Systems Evaluation Group, Washington, D.C.) ; F. D. Rossini, chairman of the Department of Chemistry, Carnegie Institute of Technology; A. B. Sabin, professor of research pediatries, Children's Hospital Research Foundation, Cincinnati ; F. Schrader, head of the Department of Zoology, Columbia University ; F. Seitz, research professor of physics, University of Illinois ; W. Shockley, research physicist at the Bell Telephone Laboratories, Murray Hill, New Jersey; T. G. Thompson, director of the Oceanographic Laboratories, University of Washington; W. S. Tillett, head of the Department of Medicine, New York University College of Medicine; G. T. Whyburn, chairman of the Department of Mathematics, University of Virginia ; C. J. Wiggers, professor of physiology, Western Reserve University School of Medicine; W. G. Young, dean of the Division of Physical Science, California Institute of Technology.

Foreign Associates : P. Eskola, professor of geology and mineralogy, Helsinki University; Sir Godfrey Thomson, professor of education, University of Edinburgh ; K. von Frisch, director of the Zoological Institute, University of Munich.

\section{CENTRAL ROAD RESEARCH INSTITUTE, INDIA}

A CONFERENCE of chief engineers of Indian A States and Provinces which assembled at Nagpur at the end of 1943 emphasized the need for a Road Research Institute. The 'Nagpur Report' recommended the construction and improvement of about 400,000 miles of various types of roads; and an efficient and economical execution of such a developmental programme obviously demanded a Road Research Institute. The question was considered by the Council of Seientific and Industrial Research as well as by the Ministry of Transport, and it was decided that the proposed Institute should be part of the chain of national laboratories being planned by the Council. Road research was to be the care of the Council, while development was to be undertaken by the Transport Ministry, the Council and the Ministry working in the closest co-operation. In 1945 the Council appointed a Road Research Planning and Advisory Committee to work out details for the proposed Institute. The Planning Committee saw great advantage in locating the Institute near Delhi, particularly as the main and arterial roads converge on Delhi. Many sites near Delhi were examined. The 32 -acre site finally chosen near Okhla on the Delhi-Muttra Road, though only about seven miles from Delhi, is really part of Uttar Pradesh, and has been presented to the Institute by the Bishop of Delhi and Simla.

The governing body of the Council of Scientific and Industrial Research received the Planning Committee's recommendations during 1948. The proposals envisage the setting up of one main field experimental station and a road test-track to carry out experiments on different kinds of road surfaces and to test their behaviour under actual road conditions. The Council is to provide funds for the establishment of the Institute and will be in charge of it, while the field experimental station will be financed and controlled by the Ministry of Transport. Dr. R. K. N. Iyengar had already in the latter half of 1947 been appointed assistant director (planning). Dr. Ernst Zipkes, a Swiss road engineer, formerly in charge of the Department of Road Research in the Federal Institute of Technology at Zurich, was appointed director, and the Research Institute has been functioning under him in a temporary laboratory at Okhla. The foundation stone of the new Institute was laid on September 6, 1950, by the Minister of Transport, the Hon. Mr. N. Gopalaswamy Ayyangar, who explained the scope and possibilities of the Institute and the importance of the work it is expected to do. The Central Institute will, among other things, co-ordinate the work of all local stations, such as those at Madras, Karnal, Lucknow, Patna, Calcutta and Poona.

Sir Shanti Swarup Bhatnagar, director of the Council of Scientific and Industrial Research, gave a brief account of the steps leading up to the establishment of the Institute. He defined its functions thus : (1) fundamental research on the behaviour of materials used in road construction, and devising of methods of measurement for this purpose ; (2) correlation of laboratory test results on standard materials with those under actual investigations, in order to enable reliable estimates to be formed of the behaviour of various road materials in practice; (3) tests on soils and a study of soil mechanics for the evolution of low-cost roads; (4) research connected with the standardization of specifications for roads and roadbuilding plant and machinery; (5) devising of instruments for various tests on roads and bridges, such as measurement of the irregularities of road surfaces, impact factors, automatic recording of traffic, etc. ; (6) studies on the characteristics of different types of road under different traffic conditions, incidence of accidents, road-safety devices and road statistics; (7) undertaking co-operative research schemes and co-ordination with engineering colleges, other research institutes and industrial concerns doing similar work, and tendering technical advice and assistance when sought; (8) dissemination of results of research and experiments by means of pamphlets, journals and films for the benefit of road engineers.

Special emphasis, Sir Shanti said, would be laid on rural roads and their development "from easily and locally available material in such a manner that they can be constructed with the help of local labour at a very low cost".

Dr. Zipkes, director of the Institute, summing up the tasks of a Road Research Institute, said : "Road research investigates how to construct in a given area the most solid and safest possible road using the 